\title{
5 Louise Ho and the Local Turn: The place of English poetry in Hong Kong
}

Douglas Kerr

2009 saw the publication by Hong Kong University Press of Incense Tree: Collected Poems of Louise Ho, a book by Hong Kong's leading English-language poet. The consecration of the poet's work by publication by an academic press says something about the institution of literature in English in Hong Kong, but so does the fact that the title refers to a tree, aquilaria sinensis, whose fruit produces the incense that gave Hong Kong its Chinese name (Incense Port), but is today, as the title poem says, an endangered species. ${ }^{1}$ The book contains work from three earlier publications, as well as a substantial body of new poems, from a writing career spanning five decades. The opening poem is entitled "Hong Kong Riots 1, 1967", and the last poem, set as its title says only "The Other Day", is about struggles of reorientation in "Ad hoc Australia", a landscape that seems to the poet in exile to lack the landmarks of culture and history necessary to bring it into visibility. "Sun scorched land lost / Purblind / I lose / My cardinal points." The story that unfolds between those riots and that reorientation is a poetic record unique in English, a Hong Kong story of colonization, decolonization, exile and diaspora - and many returns, happy and unhappy.

Among the new poems in the collection is one called "About Turn". Turning is always interesting to poets. The turn of the verse at the end of a line constitutes the visible difference between poetry and prose. Poetry works through a series of linguistic figures or tropes, a term deriving from the Greek word for "turn". Poetic metaphor is metamorphic, turning one thing into another. Poetry is also, like Homer's Odysseus, "polytropic", manyturning, both inventive and devious. The poet's craft is always a bit disreputable, like table-turning or turning a trick - "The truest poetry is the most feigning," in Shakespeare's words, and "The turn of a verse / a sleight of hand" go together, as this poem shows. Turning can be creative, it can disclose new possibilities, but we are also right to be suspicious of turning, and being turned and turned again can turn the head. "About Turn" is one of a number of poems in which Louise Ho reflects about poetry itself. But the trope of turning and being turned also turns out to be a way of talking about the context of the poetry, that of Hong Kong's "return to China".

The turn of a verse

\footnotetext{
${ }^{1}$ All quotations from Louise Ho's poetry are taken from Ho (2009).
} 
A sleight of hand

Two nations

Each taking turns

To turn us around

Leaving us

With many a confounding turn

Here the balance seems to shift between a creative turning, and a deceptive turn practiced by two nations on a helpless victim. The poem recalls the widespread sense that in the negotiations between Britain and China to decide the future of Hong Kong, Hong Kong people themselves were of little account: nothing much turned on their opinions or actions, before or after the return. The poem concludes:

In the end

We turned inside out

And that was the end

Of all that turning

To be turned inside out means to be completely bamboozled or tricked. Of course it could mean to be eviscerated. But perhaps in the jaunty rhythms of the poem's ending, and the active voice of the verb here ("We turned") is another possibility, which reactivates the creative and poetic resonances of turning. At a moment of crisis in its history a community may turn inwards to discover a new sense of itself, before turning outward again to face the world. The unexpected result of being given its marching orders - "About turn!" might be Hong Kong's discovery of where it stands, its own identity and difference, its location.

This essay is about the intersection between history and the local in the English poetry of Louise Ho.

\section{Three locations}

Louise Shew Wan Ho was born in Hong Kong, spent some of her childhood in French-speaking Mauritius, returned with her family to Hong Kong, went to university, and later taught English at the Chinese University of Hong Kong. She now spends most of her time in Australia. Here is one of her poems that is a favourite of anthologists. 
A Chinese

Invited an Irishman

To a Japanese meal

By the Spanish Steps

In the middle of Rome

Having come from Boston

On the way home.

This is not a poem of intellectual complexity or emotional intensity. Its language is neither original nor beautiful. What it does is to tell a lively story about a Chinese cosmopolitanism, apparently available to Hong Kong people, although still, in the 1980s when the poem was written, not much more than a dream to most mainland Chinese. It builds a cumulative structure that resembles that of a joke. The act of invitation narrated in its main verb is one that places the inviter in the position of host - at home, wherever the invitation is actually issued. It is a cosmopolitan illocution. Here is a life of international friendship, of eclectic taste, of frictionless mobility between scholarly, spiritual and commercial centres, old world and new, West and East. The poem, like the traveller, is in circulation, beginning and ending at "home", with the only end-rhyme anticipating the bump of arrival, the return to the starting place, laden with each line's trophy of experience or traveller's tale. What could be more desirable, simpler, or more fun? "Home" underwrites the poem, as homecoming underwrites the travelling. Local belonging is the warrant for global mobility and gives it shape. The poem first appeared in Louise Ho's collection Local Habitation (1994).

It used to be quite common to meet a disbelief that Hong Kong could be thought of as home. It was a city of exiles, populated by people who had come, for the most part, from the mainland of China in search of business opportunities or political refuge, and the wind that had blown them to the colony might just as easily carry them further in due course, to other cities in Southeast Asia, to Australia or North America. Hong Kong was a transit camp of the Chinese diaspora, a city of sojourners, economic migrants and refugees, and not a place to develop sentimental ties. From the point of view of the Chinese mainland, it was hard to imagine people feeling at home in a modern Chinese city that, however rich, differed from other Chinese cities in being the colonial possession of a foreign power, won by force legitimated by unequal treaty. Besides, since the signing of the last of those treaties in 1897, the colony's days were exactly numbered. Hong Kong in the past had not participated in the narrative of the Chinese revolution; it had no future as 
itself. Anomalously insulated, for a while, from Chinese history, to observers in the mainland it often seemed culturally empty too, a place without an inner life of its own, where materialism was the only language. As for its non-Chinese population, this was essentially expatriate, consisting of people who after a contract or a career would take their money and go home. There were reasons why people might want to live in Hong Kong, but who could really belong to such a place, or wish to?

And yet there were more than sufficient conditions of difference to constitute Hong Kong as a locality, its own place, a place of affective investment, to know and belong to. The closing of the border in 1950 (hitherto there had been free traffic of people to and from Mainland China) drew a line between the colony and the People's Republic and "turned the Chinese population of Hong Kong into a settled one" (Tsang, 2004, p. 181). If Hong Kong sometimes worried that it might be a "cultural desert", it suffered no Cultural Revolution. The colonial government, certainly not democratic, was subject to the rule of law. By the early 1970s a majority of the population was local-born. Prompted by its alarm at the repercussions of the upheavals over the border in the form of serious disturbances on the Hong Kong streets in the mid-1960s, the colonial government actively began to encourage an already emergent sense of a Hong Kong identity, crystallizing round indigenous popular music, film and television, and campaigns of civic responsibility, and articulated, for the most part, in Cantonese (see Turner and Ngan, 1995). This might seem a classic case of the emergence of identity out of difference - in this case a difference from both the colonial and the national culture that in turn differentiates Hong Kong from most other examples of postcolonial identity formation. One apocalyptic narrative of this development has it emerging, in the decade or so before 1997, only to be overtaken and swallowed up by the renationalizing of Hong Kong in China's resumption of sovereignty (Abbas, 1998). The mayfly existence of a Hong Kong subjectivity, in this telling of the story, appears poignantly only in the fleeting moment of its disappearance. It appears, to be lost. Not surprisingly, the post-1997 morphology of the phenomenon had proved difficult to descry (see Erni, 2001; Fung, 2001).

The in-betweenness, and the vulnerability, of colonial Hong Kong is the subject of Louise Ho's poem 'Living on the Edge of Mai Po Nature Reserve'. The location, in Hong Kong's northern "New Territories" near the Chinese border, is quite specific, and the scene opens in the mode of pastoral.

This garden this stream these marshes 
A bird sanctuary among the mangroves,

Herons perch egrets glide,

The hills gather from afar.

The place of nature is protected from history; nothing happens here. The scene is set with no verbs at all, then traversed by the intransitive activities of herons, egrets and hills. This first impression is deceptive, however. Within sight of this enclave are shadows of city blocks, and at night "a long row of lights like jewels" marks the electrified high fence separating the colony from Mainland China. The line of lights written across the landscape is also a sentence, in the future tense, pointing to the reclamation of Hong Kong, and the "gathering" of the hills in the first stanza starts to emerge into transitivity as the landscape reveals its animate and political meanings (for to gather means to cluster, but also to scoop up). The poem ends like this.

The horizon closes in like two long arms.

We are surrounded,

China holds us in an immense embrace.

Merely the lie of the land.

This is the first appearance in the poem of "us", the locals of this locality, who now become visible as the passive victims, or beneficiaries, of being where they are. This edgy poem about a local place twists and turns on itself with a restless ambivalence very characteristic of the divided state of mind (we might call it a structure of feeling, if "structure" didn't sound too fixed and solid) in Hong Kong in the years leading up to the transfer of sovereignty in 1997, years when the nation over the border impended increasingly over everyday life. The horizon - the future - is felt as claustrophobic, but may also be sheltering. "Surrounded" is ominous, but "embrace" is reassuring - but then "an immense embrace" seems out of scale for a gesture of maternal solace, and is, besides, not something open to dissent. Who wants, or could refuse, to be held in an immense embrace? The tropes applied to the inanimate topography of the scene begin to stir into a story, and a disquieting one; living on the edge of Mai Po Nature Reserve is indeed living on the edge. The poem's last line appears to move in to defuse the situation, and disarm the tropes of surrounding and enclosing and holding - these were after all only a manner of speaking, it seems, and the poem itself is simply a description of landscape, nothing more. "Merely the lie of the land." The last line, like the first, is verbless and static. This after all, it seems to say, is just a poem about scenery. It's a picture, not a history. But this classic démenti puts the preceding lines, we might say, under erasure, without expunging them. It contradicts what comes before, but a contradiction is not a resolution. The 
ending does not take the edge off the poem. There is, besides, the worrying ambiguity of "the lie of the land", a turn of phrase that could indicate simply topography - this is just the way the contours run, no reason to read anything more into it - but also contains a hint of duplicity, of lying (see Empson, 1972, pp. 127-59). ${ }^{2}$ And if the look of the landscape is misleading, what is misleading about it: the claustrophobia, or the embrace? Denial, a classic defensive trope, often draws attention towards what it wants not to see. Thus the poem lifts up its eyes to the Chinese horizon, but shrinks from it at the same time.

There is, however, a world elsewhere, and a third poem, 'Migratory', reaches for it uncertainly.

I floated alone in my kingsize bed

I steered between abysses

To my left 1997

To my right 1788

I hugged the shorelines

Crossed the high seas

And drifted here

Landing on terra firma

Terra Australis.

This is different from the sociable globetrotting of 'Home to Hong Kong', for this time the journey is isolating, alienating, and sounds dangerous, even in fantasy form. It is the journey of exile, and despite the new immigrant's dutifully taking note of "new shapes new sounds / And endless possibilities", the glance is drawn backwards, inevitably, to locations left behind.

At first the heart longs

For the absent familiar

Cosmopolitan Hong Kong

Its chaos, its anomalies, its power

Or England, my other world

Or some landmark somewhere

A villa by Serlio on the way

To Erbusco, outside Milan

Or family, relatives

In New York, San Francisco

\footnotetext{
${ }^{2}$ In William Empson's taxonomy, this is an ambiguity of the third type..
} 
Vancouver, Toronto...

Then, like lightning

The shock of the void struck.

In this drifting sentence the poem turns for consolation to a nostalgic reverie of being once more at home in the world, in an easy drift of memory across favourite places ("Just reeling off their names is ever so comfy", to appropriate Auden), a sort of global freedom like that enjoyed in 'Home to Hong Kong'. But that earlier cosmopolitanism was anchored and guaranteed by the local groundedness from which it departed, to which it could always return; and here in 'Migratory', as the title had warned, that groundedness is no longer a given. Hence the interruption - "like lightning" - that shows up that catalogue of geographical alternatives as empty air. The shock of the void "struck" - the historic tense is an ungrammaticality, incongruent with the present tense in which the sentence started, yet functioning paradoxically to drag the mind back to the present, from "the absent familiar" to the alien here and now, to having to live in history.

Meanwhile, Australia in 'Migratory' is not so much a place as the loss of place, a dislocation. This may seem unfair - after all "The neighbours are kind, the dogs are friendly / The land is veritable Eden" - but these amenities can only be enjoyed by someone who is really there, who has successfully negotiated the enigma of arrival and made landfall.

\section{Space-tost, land-lost \\ I float, I drift, I hover \\ Cannot settle \\ Cannot come to stay....}

Hovering, a recurrent idea in Ho's poems, is not bad in itself, but here it indicates an incomplete exchange of places, one land lost (as in 'The Other Day', "Sun scorched land lost") and a new one not yet inhabited. For the cosmopolitan the globe is mapped by pathways, relationships, histories, but the would-be migrant is adrift over a landscape without known landmarks, the subject pronoun helplessly repeating itself only to state its lack of agency and purchase. The southern landscape is seen as an existential void, and the migrant needs to embark on the discursive task of knowing it - "Measure the land / Foot by foot / Step by step" - so as to acquire the weightiness to "Sink the ankles / Touch the ground / Walk normally". It does not seem an extravagant ambition. Measures, and feet, belong to the language of poetry as well as to that of surveying, for poetry too is a 
form of knowledge, both a cartography and a way of asserting tenancy in a place claiming it, and settling it, hopefully without the bitterness these actions inherit from Australian history. There is, of course, an Australian precedent for the discourse of inhabitation that this poem enacts or promises: 'These are my songlines':

Claiming by declaiming

Over my land

O land, walk with me

May the dust settle

Wherever I may stand.

Migration is a turn without a return. But relocation makes possible, though it does not guarantee, a new and much more difficult kind of freedom, one that is not given but made. In 'Migratory' we see it establish a narrow and precarious foothold, where the home left behind is replaced by a more abstract location, a modality and subject position, wherever the subject pronoun makes a stand. But in this move, 'Migratory' is paradigmatic of Louise Ho's poetry as a whole. For the Hong Kong poet of her generation, who has known a Hong Kong colonized, internationalized, globalized, decolonized, and renationalized, locality - a place to belong to - has always been something to be created, brought into being, through writing. Writing is a way of finding your feet. One thing that makes Louise Ho particularly interesting is that she finds hers in English.

\section{The place of English}

Trade and empire spread European languages around the globe. No one thinks it odd that Borges wrote in Spanish: the former imperial language is the national language in Argentina. Nor is it mystifying to find a great Indian writer like Narayan using English, an option that was a way of reaching a large readership of his own countrymen in a multilingual nation, besides others around the world. But Hong Kong is a Chinese city, full of Chinese people, and there is a Chinese language, with, of course, an incomparable literary tradition. Why articulate a modern Hong Kong Chinese experience in a residual colonial English language brought to the China coast with the traders, the missionaries, and the gunboats of empire? 
In Hong Kong it was never, to be sure, a simple choice or contention between a local language and that of a distant imperial authority (see Hutton, 2006). For one thing, there was already an imperial, Mandarin, language in China. Cantonese, incidentally fostered and promoted by Western missionaries and ideologues as a regional identity independent of the Chinese empire, became the language of the local, the community's "mother tongue". Cantonese was the organic alternative to the colonial language, and both played a more important role in forming the territory's sense of itself than (first) the imperial and (after the Revolution) the state or national language of China. In such circumstances it cannot be adequate to claim that Chinese is the local language in Hong Kong. Further, the existence of a literature in English in Hong Kong, however tenuous, at least makes it a little harder to think of the place in terms of the hoary binarism of West and East. ${ }^{3}$ Finally, with the anticipation of renationalization in 1997 and now in its aftermath, there has been a very significant increase in Putonghua speakers, and Putonghua use, in Hong Kong.

Cantonese however remains overwhelmingly the language of common speech and popular culture, but the fate of Cantonese was, for some, one focus of an anxiety about the consequences of a homogenizing renationalization. So we have the apparent anomaly of Louise Ho, in 'Flags and Flowers', using English to make a plea for Cantonese after the handover, in what looks very like a version of a trope belonging to the nativist phase of postcolonial discourse. "Change our flag as you must / But let us keep our speech", the qualities of that local speech being the expression of a locality but also - since it is believed that Cantonese is phonologically closer to older forms of Chinese - an important bearer of an ethnic tradition.

Our local voices

Our nine tones

Our complex homophones

Our own configurations of meaning

Our own polite formalities

Our resonances from the Hans of old.

What does it mean for a Hong Kong Chinese writer to use English? The more common postcolonial scenarios do not apply: English is not the national language in Hong Kong, nor a linguistic hegemon threatening to engulf a relatively weak indigenous

\footnotetext{
${ }^{3}$ For recent Hong Kong literature in English, see Xu and Ingham (2003), which has a foreword by Louise Ho.
} 
language, nor the only medium available whereby a local writer might hope to reach a larger readership. English is, to be sure, a "world" language in a way that Chinese at the moment is not, and the literary-historical paradigm influentially proposed by Pascale Casanova in The World Republic of Letters may help us to think about this, if only up to a point. Casanova argues that what she calls "world literary space" is now organized in terms of an opposition between an autonomous "literary and cosmopolitan pole" on one side, and a heteronomous "political and national pole" on the other. ${ }^{4}$ Her contention that the latter is "composed of relatively deprived literary spaces at early stages of development" can scarcely apply to either the traditions or the institutions of Chinese writing; however, there is more potential explanatory power in her view that the internal configuration of each national space is similarly bipolar in structure, and shaped by a rivalry between what she calls “"national' writers (who embody a national or popular definition of literature) and 'international' writers (who uphold an autonomous conception of literature)" (Casanova, 2004, p. 108). International writers in Casanova's sense are those who, often in exile, seek greater freedom for their work in a turn to a common "universal" measure of literary value, authorized in a "denationalized" universal capital, such as Paris, through metropolitan aesthetic models, publishing networks, and critical functions. ${ }^{5}$ The turn to the metropolitan and universal is a turn away from the peripheral and local. What clearer sign of this intent than to write not in a national language like Chinese but in an international language like English? ${ }^{6}$

To assess how useful this is as a way of thinking about Hong Kong writing in English, it is instructive to consider a neighbouring case, that of the body of Englishlanguage poetry written by Malaysian Straits-born Chinese, principally Ee Tiang Hong and Wong Phui Nam. These writers grew up in the ethnically and culturally distinct Baba communities of the peninsula, but fell foul of the nationalist myth of the Bumiputra (son of the soil) promoted in postcolonial Malaysia, assisted by a traditional resentment of the commercially successful Chinese minority and a vigorous promotion of Bahasa Malaysia, displacing English in education and public life, as the national language. Some writers, notably the poet Muhammad Haji Salleh, gave up working in English to devote themselves to nationalist cultural projects and the Malay language. Others, like Ee and

\footnotetext{
${ }^{4}$ These modalities are understood by Casanova to stand in oppugnancy, rather than, for example, in dialogue; the model seems to be one of economic rivalry or even military hostility. If letters is a republic, it is in a state of civil war.

5 "Every work from a dispossessed national space that aspires to the status of literature exists solely in relation to the consecrating authorities of the most autonomous places" (Casanova, 2004, p. 109).

${ }^{6}$ Also of relevance to this question of internationalization is the anthology of translations edited by Louise Ho and Klaus Stierstorfer (2006).
} 
Wong, though Malayan born and in Ee's case Straits Chinese of the seventh generation, experienced the distinctly cold shoulder of "Malaysian Malaysia". "The alienation of the Baba Malay, as in the case of Ee Tiang Hong," writes the Singaporean scholar Rajeev S. Patke, "shows how the political idea of autonomy was fetishized along exclusionary, nativist and fundamentalist lines" (Patke, 2003, p. 73). And as language policies in Malaysia drained English out of the national life, the English-using poets who stayed on found themselves increasingly marginalized and beleaguered in terms of readership, publication and sponsorship. Wong Phui Nam, whose first language was Cantonese, reflects gloomily on the predicament of the writer of verse in English in Malaysia in his essay 'Out of the Stony Rubbish', with its title's quotation from Eliot flagging its affiliations with a distant metropolis, where furthermore Ways of Exile, the book containing the essay, was published (Wong, 1993). The rivalry Casanova finds between internationally oriented writers and those involved in the nation-building project could hardly be more clear-cut than in this instance.

Wong Phui Nam finds a theme in the traditional ways and minority practices including the "scant inheritance" brought from China by his impoverished migrant ancestors (Wong, 1993, p. 134) - now disregarded or worse in the homogenizing vulgarity of a new nation, and becoming unavailable, lost to decay and exile. The cast of his own literary identity in English is itself part of the tragedy, for writing in English not only limited his readership at home and might even be construed, as Alan Durant says, as "a form of cultural dissent" in nationalist Malaysia (Durant, 1993, p. 150), ${ }^{7}$ but also seems not to have compensated him with a sense of being at home in the other language. In internal exile in the culture of his own country, his facility in English does not provide him with a passport to citizenship of the world, for the history inscribed in it keeps reminding him that it belongs to somebody else.

To internalize a language is to allow it and the broad assumptions that the community of its native speakers hold about the universe to become a part of oneself. The non-English writer who writes in English and has no similar recourse to his own language is thus, in allowing English to take over his affective faculties, in a very deep sense a miscegenated being, very much and yet not an heir to the tradition of Shakespeare and Milton. The language he uses to name, organize and express his

\footnotetext{
${ }^{7}$ The essay by Durant, a London professor of English, appended to this collection of Wong's poems is, it could be argued, a further instance of Casanova's "international" writing's bid for consecration by metropolitan authorities.
} 
experience of the life around him removes him from that life and, whether he is aware of it or not, he becomes a stranger cut off and always looking in as an outsider into that life. In that sense, the more facility he has with the adopted language, the more unauthentic he becomes. Culturally and so, spiritually, he is induced to place himself in exile from England and be cast out of an imagined Eden (Wong, 1993, p. 140).

The intellectual integrity of Wong Phui Nam's position is due the greatest respect, and so is the creativity of his response to this dilemma, a process he describes as involving "a flooding out of English words with one's own immediate apprehension of the world to clean out their traditional English connotations whenever they intrude inappropriately into the texture and feel of the writing" (Wong, 1993, p. 141). But having said this, it seems also important to say that Wong's dilemma is not one than can be generalized as an affliction of all English-language writers in what Casanova calls "peripheral" literary spaces. Certainly the language has to be adapted to express local experience - and the creativity of such transformations by postcolonial writers is by now a truism of the literary history of English - but the distance between that experience and the habits and conventions established in the metropolitan tradition need not necessarily burden the writer with fears of inauthenticity. To turn to English does not have to entail turning one's back on one's own place, Nor is it always necessary, desirable, or possible, to purge English of its accumulated connotations.

There are several reasons for this. First, what Wong describes as "the native tradition" of English poetry never had a stable centre, or rather its centre was always subject to continuous shifts under the pressure of revolutions and reformations in idiom and subject matter from various points of what had been the periphery (Dryden and Wordsworth being as revolutionary, in this narrative, as Robert Burns or Gertrude Stein), a process that Malaysian or Caribbean or Hong Kong English poets honour and continue. Second, the character of local poetry in English is not just the product of the agon of the peripheral poet with the metropolitan, formerly colonial, language. Rather, as Bruce Clunies Ross has shown in an important essay, it is marked by the complex linguistic interactions of the local scene itself, and these may include several varieties of English as well as different forms of indigenous speech and writing. "It is these," says Clunies Ross, "and not the imperially transposed English heritage, which impel the creation of poetic 
language" (Clunies Ross, 2004, p. 312). Third, Wong Phui Nam's frustration at being, as a poet in English, "a stranger cut off and always looking in as an outsider into [the life around him]" is perhaps well answered by Louise Ho herself in her observation that "[1]iterary language is an alienated language, anyway" (Ho, 2002, p. 175). A poet is always in some sense a stranger. Formally and rhetorically - and institutionally too poetic writing is already apostatic, standing aside; though it must be rooted in ordinary discourse it is also a divergence from it, and would not otherwise be poetry.

Louise Ho appears quite content to work with a language that might be thought a colonial residue, or a cargo of inappropriate and distorting associations, without seeking to purge it of its traditions, which on the contrary she is quite ready to make use of, or to sport with. At times she uses Cantonese words or sounds within her English poems (as in the macaronic 'Jamming', with its carnivalesque Cantonese nonsense-refrain, "geeleegulu"), ${ }^{8}$ and describes one of her goals as the creation of "a space where the English literary language expresses as well as is incorporated into the local ethos, thus becoming almost a tertium quid, but which remains at the same time definitely English" (Ho, 2002, p. 176). At the same time, while certainly oriented outward to international readers and outlets, she is from beginning to end a poet of Hong Kong experience and history. And while hers is not the kind of work readily harnessed to nation-building projects or a national moral and aesthetic agenda - far from it - nor is it shaped by a rejection of local aesthetic and linguistic practices, especially as instantiated in Cantonese. The poem 'Well-Spoken Cantonese', in Local Habitation, describes an eloquent man, and ends like this:

His modulated resonance

Creates a civilized space

Or a proper silence

Which was not there

Before he spoke.

The medium of written English and the subject of Cantonese speech collaborate, as it were, to make "a civilized space". Language builds the city.

The Chinese-language Hong Kong poet Leung Ping Kwan tells a story about a proposed book of poems and photographs (the latter by Lee Ka Sing), on the theme of

\footnotetext{
8 "Geeleegulu" is glossed in a note as "Double Dutch"; it is the kind of burbling with which infants are sometimes addressed by besotted adults. Varieties of English also jostle in the poems. In 'The Australian O', a favourite word is reborn as "heaoaium".
} 
"home", which never saw the light. It was to have been about what happened in China in 1989. Squeezed out of publication space by the publisher's failure of nerve or the requirements of the market, Leung's poems were in danger of becoming homeless. But later he worked with the American poet Gordon Osing on turning them into English, so that "these poems of mine, which had found no chance of publication in Chinese, were able to move into what looked like a temporary home in the space provided by a foreign language" (Leung, 1998, p. 89). ${ }^{9}$ It was an important moment in the establishment of Leung's wider reputation. Perhaps it signalled his arrival in Casanova's international literary space. But to the poet himself it felt like the securing of a home space, so that at the time Lan Kwai Fong, the bar district where they met to talk about the collaboration, became for him something of a local allegory.

Lan Kwai Fong always makes me think of Hong Kong. The space we have is a mixed, hybrid space, a crowded and dangerous space, carnivallike even in times of crisis, heavenly and not far from disasters, easily accessible and also easily appropriated - by political, economic, and other forces. Is there anything we can do to ensure this remains an open space for all? What appears to be prudence can easily turn in to selfcensorship; what seems to be free speech can easily infringe upon other's freedom. All sorts of pressures and interpersonal relations keep intervening, affecting how we use words and images to express ourselves and communicate with others. This space that is open to us can all too easily be lost to us. And, without a home that is friendly, stable, and tolerant, we can only drift from place to place lugging with us our words and photographs (Leung, 1998, p. 95).

This is home as locality, and it has more than one language.

There is, at least, no official hostility to English in Hong Kong, as there was until recently in Malaysia. Hong Kong government officials and educators speak piously of a wish to create a "biliterate and trilingual" civil service and, eventually, society. ${ }^{10}$ In the jittery 1990s, when post-handover postures were being rehearsed, there was some tendency to decry English as the language of colonial oppression, though much of this disappeared when it became clear that the Chinese central government regarded English as

\footnotetext{
${ }^{9}$ The Leung-Osing collaboration is Leung, 1992.

${ }^{10}$ The policy is set out in the written reply of the then Secretary of the Civil Service to a question put in the Hong Kong Legislative Council, $5^{\text {th }}$ July 2006. http://www.csb.gov.hk/english/info/326.html, accessed $23^{\text {rd }}$ June 2009. Biliteracy in Chinese and English, and trilingualism in Cantonese, Putonghua and English is the aim.
} 
the language of global business. And herein lies the really important factor for the English-language writer in Hong Kong, for if there is a significant linguistic-ideological rivalry to contend with, it is not with classical written Chinese, Standard Written Chinese, Putonghua, or Cantonese, or even the Great Tradition of English poetry, but with the mighty ambient drone of the variety of English that Michael Toolan has christened Global (see Toolan, 1997; and Toolan, 'Nation Languages').

For there is a kind of English that is a prized commodity precisely because it is alocal; it goes everywhere and belongs nowhere, its defining characteristic being not a surplus of associations and affiliations, but an emptiness of these things. This tumbleweed English is entirely instrumental, an English for data and proposals and sales pitches but not for ideas, for negotiating postures and "social talk" but not arguments and conversations. Adrift from location, intellectually weightless and bleached of history, this is a kind of language poorly equipped to help its users pay critical attention to where they are, for they might indeed be anywhere. Michael Toolan characterizes Global as a non-creolizing pidgin, a "second-language language", one whose "locality-free de-culturating" renders it "denatured, artificial, geared to pragmatic or profitable ends" (Toolan, "Nation Languages'). A speedy informational language unbothered by culture or history, uncluttered by nuance, ambiguity or abstraction - anyone who has been into an Englishlanguage bookshop in Hong Kong or scanned the advertisements for tutorial schools (or indeed met some Hong Kong students) will know that this is what many want from English. The drowning out of humanistic values by discourses geared to the "informationalization of knowledge" in a fast globalizing economy seemed to Rey Chow who grew up in Hong Kong in the 1960s and 1970s - to have got off to an early start in the colonized world, in places such as Hong Kong, though the process as she sees it is now globally pervasive. "Indeed, on the Chinese mainland itself, the informationalization of knowledge these days includes frenzied attempts at popularizing the English language as information, with words and phrases reiterated by masses like political and/or commercial slogans" (Chow, 2005, p. 52). The aspirations for financial reward and socioeconomic standing that fuel this desire for instrumental English are not to be despised. ${ }^{11}$ But they are part of a situation that "adds value" (ironically enough) to the different kind of

\footnotetext{
${ }^{11}$ Indeed, teachers of literature in English are very aware that the primary motivation of most of their students, and the families who support them, is the enhanced career prospects enjoyed by those who have majored in English studies at university. Not surprisingly, it is not only in Hong Kong and Mainland China that this is the case. See Lukmani, 1993. Several of the essays in this volume - whose main title is without deliberate ambiguity as far as I can see - are pertinent to the question of English and education in Hong Kong.
} 
language that can produce reflective and humanistic knowledge, a knowledge that is not information but cultural memory, consciousness and conscience. This is what poetry is for.

\section{A place to stand}

The shadows of June the fourth

Are the shadows of a gesture,

They say, but how shall you and I

Name them, one by one?

Louise Ho's poem 'Remembering $4^{\text {th }}$ June, 1989' asks difficult questions about memory, the memory of the national crisis named in its title, and it does so in an inflection set by Hong Kong and by English. In this, it is another episode in this poet's long commentary on the history of her own times and places, stretching back to two poems about the Hong Kong riots of 1967, and commemorating cultural, demographic, and architectural changes, besides events such as the 1997 handover itself. It is a historical record, the poetry being witness to a changing structure of feeling in a place that has been, whatever else, both unique and exemplary as the site of so many of the shaping forces of modern times. 4 June 1989 is one of the most painful moments in that history, and cast more than one long shadow, not least in Hong Kong, where the unfolding events in Tiananmen Square were followed with an attention sharpened by the certain prospect of a return to Chinese sovereignty in eight years' time. So the job of remembering the event, and naming its shadows, is an urgent and very difficult one for the Hong Kong poet. All the more bizarre, then, the opening stanza of this memorial poem.

'Remembering $4^{\text {th }}$ June, 1989'

Yes, I remember Marvell, Dryden,

Yeats, men who had taken up the pen

While others the sword

That would have vanished

Were it not for the words

That shaped them and kept them.

This seems no less than perverse. The solemn mnemonic duty enjoined by the poem's title veers off immediately, in the first of the poem's many turns, into a different kind of remembering, a naming instead of three canonical English poets, and the revisiting of a 
truism ("the pen is mightier than the sword") that in context just looks smug: in the end, it's poetry that matters more than political action, because poetry is not ephemeral. It looks as if the poem has already broken the promise of its title, and instead of remembering 4 June 1989 it is commemorating Marvell, Dryden and Yeats in an evasive trope that turns the poem away from its difficult agenda and immediately buries its head in the golden treasury of the English tradition. Scandalously, the poem seems to be just asking to be dismissed as proof of the distance between "English poetry" and Hong Kong experience, and the hopeless irrelevance of the former to the latter. But of course it is when we bring these two fields of knowledge together that this opening gambit makes sense. What it affords is not just a "cross-cultural" moment, but one in which Chinese experience is seen from within through the optic of English.

Dryden, Marvell and Yeats - two seventeenth-century poets and one twentiethcentury one - are no random selections from the canon, but are, as the poem says, writers whose work participated in and interpreted the great public events of their times. John Dryden - dramatist, satirist, historiographer royal and poet laureate of the Restoration court - was a loyalist to the precarious political authority of Charles II (and later James II) over a country still riven with religious and ideological divisions in the aftermath of the Civil Wars and Cromwell's Protectorate. The political affiliations of Dryden's older contemporary Andrew Marvell, were different; he was a friend and assistant of Milton and sometime tutor to the family of the parliamentary general Fairfax, and himself a member of parliament during the Cromwellian Protectorate and the Restoration. These men, in the century of the English Revolution, produced some of the most trenchant political poetry in the language, and can stand for later poets as models of possibility - for loyalism, dissent, satire, polemic, tragedy - in the response of the writer to times of political turmoil and rebellion, times too when the publication of a poem might well be not just a political intervention but also a calculated political risk. Marvell's poem 'An Horatian Ode upon Cromwell's Return from Ireland' (1650) - the Oxford Companion to English Literature calls it "the greatest political poem in English" - while it seems to celebrate Cromwell as a selfless revolutionary hero, has been especially prized for its judicious and even-handed account of both sides in the conflict between Charles I and Parliament, and its famous description of the execution of the King. Such is Marvell's mastery of inclusive irony and ambiguity, and so deft is his footwork in the poem, that there is still debate as to just 
where he stands. ${ }^{12}$ It was written, in the year after the King's death, to commemorate Cromwell's return from his ruthless and bloody campaign to crush opposition in Ireland.

The point of this seventeenth-century excursion is to suggest how English poetry can work in a Hong Kong poem, how its history and associations - perhaps the very things that embarrassed Wong Phui Nam - can be mobilized both as a modality, a point of view on things from a certain experience, and as a code. ${ }^{13}$ English poetry has a history of thinking about political power and opposition to it, which is activated in the way this poem triangulates Marvell, Dryden and Yeats, thus creating an intellectual location that can be in effect a locus standi, the turn to English poetry providing a standpoint, or footing. A history inscribed in the words and names of English provides this other place, within the poem, from which its topic - remembering 4 June 1989 - can be contemplated. A place to stand enables a way of looking. The complexity - ambiguity indeed - of this poetic history prevents this move from being simply an orientalizing trope in which a Chinese experience is to be stuffed into the procrustean model of somebody else's protocols, or condemned to be seen as just repeating actions and responses performed in some other time and place. The third poet invoked, Yeats, shows this most clearly.

'Remembering $4^{\text {th }}$ June, 1989' orients its subject in relation to Marvell, Dryden, and Yeats. Marvell and Dryden then disappear from the poem, but Yeats remains a crucial reference point - as he is, in my view, by a long chalk and in many ways the most important English poet (English-language poet, that is, for he was not an Englishman) for Louise Ho. It is important that this poem is cast in the form of talk, and indeed seems to start in the middle of a conversation: ${ }^{14}$ it is responsible to an offstage interlocutor, answered in the opening words, addressed later as "My friend", and embraced from time to time in the communal pronoun "we". In the poem that pronoun is a prolocution of the Hong Kong people in general ("it is we, / Who, riding on the crest of a long hope, / Became euphoric") and of the sharers of this conversation in particular ("how shall you and I / Name them, one by one?"). This shows that these reference points, and particularly

\footnotetext{
${ }^{12}$ Marvell attracted Empson's admiring attention in three of the chapters of Seven Types of Ambiguity; see especially 196-204. For a recent episode in the debate about the Ode, see Moore, 2003.

${ }^{13}$ This leads me to dissent, obviously, from Ackbar Abbas's strange view that "English literature figures in Louise Ho's work, we might say, somewhat like the Don Quixote figures in Pierre Menard's" (Abbas, 1998, p. 125). If we think of the mobilization of the language of canonical English poetry as switching on or giving access to a kind of knowledge that then operates as another code within the new poem, we might return to 'Home to Hong Kong', for example, and note the spooky resonance of the Spanish Steps as not just a tourist destination but a signifying English site, that of the death of Keats in 1821 in a house overlooking the Steps; so that the comedy of the globetrotting Chinese poet takes place in the shadow of the tragedy of the exiled English poet, whose name was "writ in water" and who never went home.

${ }^{14}$ It takes its place in an interesting little genre of English poems that begin with the word "Yes".
} 
the recurring "remembering" of Yeats, are not to be taken just as part of the poet's singular experience, but of a shared culture and common language belonging to those educated in English in Hong Kong - a speech community, or more accurately a community of literacy.

Here the aptness of Yeats to the Hong Kong situation is especially rich, for Ireland and Hong Kong stand at either end of the history of the dismantling of the British Empire in the twentieth century. Both Irish and Hong Kong writing can be read, with due account of the difference of their circumstances, in ways opened out by developments in postcolonial studies. Yeats, the Irish poet using English, takes as his great theme the revolution through which Ireland lived in his own lifetime. "He rises," as Edward Said finely says, "from the level of personal experience to that of national archetype, without losing the immediacy of the former or the stature of the latter" (Said, 1985, p. 23). Yeats's engagement with the Irish predicament could be painful, even violently so, and a critical example is his poem 'Easter 1916', about the anti-colonial rebellion on that date in the streets of central Dublin, which was crushed after six days by British troops, its leaders later court-martialled and executed. Yeats, himself awkwardly situated as a member of the relatively privileged Protestant Anglo-Irish minority, was no great admirer of the rebellion's leaders, and was unconvinced of the efficacy of direct action at this time in Ireland; nonetheless, he acknowledges the rebellion as a seminal moment, both heroic and tragic, in his country's history, in fact a moment of nation formation. 'Easter 1916' keeps returning to this idea of violent transformation. "All changed, changed utterly: / A terrible beauty is born."

It is in particular to summon up 'Easter 1916' that the ghost of Yeats is invoked at the start of 'Remembering $4^{\text {th }}$ June, 1989', another poem commemorating fearfully a critical moment in history, and the painful ambiguities of the Yeats poem help to place the complex feeling of Hong Kong Chinese in that month as the Tiananmen events unfolded, when an unprecedented political consciousness expressed itself, with demonstrations of up to half a million people on the streets, in solidarity with the Tiananmen students and in a patriotic idiom. ${ }^{15}$ For the Hong Kong poet as for the Irish poet in his time, the question is how a poet ought to respond to, name, and remember, a desperate moment in history, arousing painful and divided emotions as it happens, and bringing consequences - like a stone cast into water, in Yeats's image - whose implications will take a long time to ripple

\footnotetext{
${ }^{15}$ Steve Tsang gives a figure of over half a million for the demonstrations in Hong Kong on 21 May and on 5 June 1989 (Tsang, 2004, p. 246, p. 247). These marches were notable, like the Tiananmen demonstrations themselves, for patriotic slogans and songs.
} 
out from the centre. The focus of the poem is not so much on China as on Hong Kong itself, and on the way events over the border catalyzed, in the territory divided and uncertain and anxious about its own future, a sense of itself as a single community - what I earlier called a locality.

Before we went our separate ways again,

We thought as one,

We spoke as one,

We too have changed, if not 'utterly'

And something beautiful was born.

As we near the end of an era

We have at last

Become ourselves...

This moment of becoming does not crystallize into a political resolution (it's hard to see where the agency for such a resolution could have come from for Hong Kong people in 1989) but is an awareness that was not fully there before. The problem of 4 June and its aftermath for people in Hong Kong was a problem of where to stand. "Whoever would not [...] Rejoice at a return / To the Motherland?" On the other hand, 4 June created a fear of the future that might outweigh even the miseries of alienation and exile (in a phrase remembering a poignant image of homelessness, the figure of Ruth in Keats's Nightingale ode) - "rather pick ears of corn / In a foreign field". Realizing where you are entails realizing who you are, and only then can freedom be a possibility. The first-person pronoun returns at the end of 'Remembering $4^{\text {th }}$ June, 1989' with a newly sharp sense of its modality or locus standi, a footing now understood to be precariously narrower than the foot itself. It craves wary walking.

Ours is a unique genius,

Learning how to side-step all odds

Or to survive them.

We have lived

By understanding

Each in his own way

The tautness of the rope

Underfoot. 
The intelligence, poise and integrity of poems such as 'Easter 1916' and Marvell's 'Horatian Ode' have played a part in bringing this predicament into visibility. Nonetheless it is quite specific, a moment of Hong Kong autobiography. The tightrope is an uncomfortable location, yet suited to Hong Kong's "genius" - a predicament, but also a performance, the balances and the turns in which Hong Kong's future will be played out in the open.

My focus on questions of location, on English, and on Hong Kong's turns and stances, has meant I have neglected Louise Ho's aesthetic subjects, yet these, with her satirical themes that I have also not had room for, make up a large portion of her repertory. To consider now her poem about a sculpture, 'Bronze Horse', will not however involve a move away from the political, any more than we move away from the political if we move from Yeats's 'Easter 1916' to his 'Leda and the Swan'. The sculpture in question, called 'Man, Horse', is a representation of a horse on its back, legs in the air, its neck hanging down and mutating into the torso and legs of a man. ${ }^{16}$ It is the work of the Hong Kong artist Antonio Mak (Mak Hin Yeung), who died in 1994, the year in which the poem appeared in Local Habitation. Like plenty of other poems in that collection, the poem's relation to Hong Kong's own approaching metamorphosis in 1997 does not need to be spelled out. (Chinese leaders were at pains to reassure Hong Kong people that what they supposed were Hong Kong's favourite pursuits - horse-racing and dancing - would continue in the territory after the transfer of sovereignty.)

\title{
'Bronze Horse'
}

\author{
Earth is kind \\ to fall of sparrow \\ fall of horse. \\ Iron ore, \\ ungiving, \\ props up \\ sculpted bronze head \\ as it breaks its back \\ on iron pedestal,
}

\footnotetext{
${ }^{16}$ The poem 'Bronze Horse' in Ho, 1997 is accompanied by Louise Ho's sketch of the sculpture (p. 74). Photographs of 'Man, Horse' and other work by Antonio Mak can be accessed via the Hong Kong Art Archive, at http://web.hku.hk:8400/ hkaa/hkaa.
} 
its legs

flaying the air.

Tree trunk neck

Sprouts athlete's legs.

Taut thighs

direct downwards

where horse's head

would have arched upwards.

Two motions clash

like trains

into each other's velocity,

two bodies

countermining,

two contraries

forced into one orbit:

the unseen body,

fully in control,

meets the unseen head,

losing control,

at the neck

of a bronze horse.

Here are brought together two subjects - the horse, and the human figure - with a rich history in sculpture, East and West. The image in monumental form most often carries a meaning of mastery, the horse a symbol of the strength of nature and the rider representing the domination of nature by the human, and hence political or military authority. In Mak's sculpture horse and man are both in trouble, abject, in painful postures, and incomplete. In this grotesque configuration they cannot possibly belong together, yet they do, contradicting each other but constituting a single thing. And at the same time the image has a strange beauty, of a transition arrested in seamless mid-process, at the moment of the birth of something new. This is a poem of the aesthetic moment, the creation of something still, well-formed and permanent (aere perennius, indeed) from a turbulent and agonizing process, at once violent and held in perfect balance. Here the trope is a miraculous turning-into, horse turning into man or man turning into horse, both of them 
headless and sightless, unconscious of themselves or each other. This is history in the moment of its making, unable to know itself. The birth of beauty out of conflict and violence - "a terrible beauty" - is a powerful and recurring theme in Yeats, whose "contraries" again haunt this poem: this is another case in which the knowledge inscribed in English poetry has helped the Chinese poet to see the subject, which is nonetheless an organic expression of its own place and time - Hong Kong, and its own metamorphosis. The poem is entitled 'Bronze Horse', but it is not about a horse (any more than the sculpture is); it is about a place of fabulous meeting, a contact point of different worlds. Pared down to a minimalist descriptive language, the poem holds its contradictions in balance to be contemplated. There are more ways than one of knowing your place.

In case this essay should have given an over-solemn impression of this vigorous and often satirical poet, I will end with a short recent poem, 'Skeltonics'. It is an impeccably traditional English poem, using a form of verse invented in the late fifteenth century by John Skelton, a scholarly poet with a sardonic eye for politics and manners. It turns on a single rhyme and tells all you need to know about the history of Hong Kong in the decade since 1997.

Ten years on and what have we got

Good times bad times the lot

The first headman was put on the spot

Up North noticed the snot

And made him trot

The new man a sot he was not

Still he wasn't all that hot

Before the dreaded slot

Everybody said the city would rot

But nothing has gone to pot

Oh no oh no we have not lost the plot.

[This is a revised and expanded version of an essay, "Locating Louise Ho: The Place of English Poetry in Hong Kong", in Critical Zone 3: A Forum for Chinese and Western Knowledge, eds. Douglas Kerr, Q. S. Tong and Wang Shouren (Hong Kong and Nanjing: Hong Kong University Press and Nanjing University Press, 2008) 15-36.] 
Abbas, Ackbar (1998) Hong Kong: Culture and the Politics of Disappearance (Hong Kong: Hong Kong University Press).

Bolton, Kingsley, ed. (2002) Hong Kong English: Autonomy and Creativity (Hong Kong: Hong Kong University Press).

Casanova, Pascale (2004) The World Republic of Letters, trans. M. B. DeBevoise (Cambridge, MA: Harvard University Press).

Chow, Rey (2005) An Addiction from Which We Never Get Free, New Literary History 36, pp. 47-55.

Clunies Ross, Bruce (2004) 'Rhythmical Knots': The World of English Poetry, in Christopher Prendergast (ed.) Debating World Literature, pp. 291-318 (London: Verso).

Durant, Alan (1993) Making One's Language as One Goes Along: Wong Phui Nam's Ways of Exile, in Wong Phui Nam, Ways of Exile, pp. 145-57 (London: Skoob Books).

Empson, William (1972) Seven Types of Ambiguity, $3^{\text {rd }}$ edition (Harmondsworth: Penguin).

Erni, John Nguyet (2001) Like a Postcolonial Culture: Hong Kong Re-Imagined, Cultural Studies 15:(3/4), (2001), pp. 389-418.

Fung, Anthony (2001) What makes the Local? A Brief Consideration of the Rejuvenation of Hong Kong Identity, Cultural Studies 15(3/4), pp. 591-601.

Ho, Louise (1994) Local Habitation (Hong Kong: Twilight Books).

Ho, Louise (1997) New Ends Old Beginnings, intro. Michael Hollington (Hong Kong: Asia 2000).

Ho, Louise (2002) Hong Kong Writing and Writing Hong Kong, in Kingsley Bolton (ed.) Hong Kong English: Autonomy and Creativity, pp. 173-82 (Hong Kong: Hong Kong University Press).

Ho, Louise (2009) Incense Tree: Collected Poems of Louise Ho (Hong Kong: Hong Kong University Press).

Ho, Louise and Klaus Stierstorfer, eds. (2006) Hongkong: Poems / Gedichte (Tübingen: Stauffenburg).

Hutton, Christopher (2006) Writing and Speech in Western Views of the Chinese Language, in Q. S. Tong, Wang Shouren and Douglas Kerr (eds), Critical Zone vol. 2, pp. 83-105 (Hong Kong and Nanjing: Hong Kong University Press).

Leung Ping Kwan (1992) City at the End of Time, trans. Gordon T. Osing and Leung Ping Kwan (Hong Kong: Twilight Books).

Leung Ping Kwan (1998) The Sorrows of Lan Kwai Fong, trans. Martha P. Y. Cheung and Leung Ping Kwan, in Martha P. Y. Cheung (ed.) Hong Kong Collage: Contemporary Stories and Writing, pp. 85-95 (Hong Kong: Oxford University Press). 
Lukmani, Yasmeen (1993) Attitudinal Orientation towards Studying English Literature in India, in Rajeswari Sunder Rajan (ed.), The Lie of the Land: English Literary Studies in India, pp. 156-86 (Delhi: Oxford University Press).

Moore, Peter R. (2003) The Irony of Marvell's 'Horatian Ode', English Studies 84(1), February, pp. 33-56.

Patke, Rajeev S. (2003) Nationalism, Diaspora, Exile: Poetry in English from Malaysia, Journal of Commonwealth Literature 38(3), pp. 71-85.

Said, Edward W. (1988) Nationalism, Colonialism and Literature: Yeats and Decolonization, Field Day Pamphlet no. 15 (Lawrence Hill, Derry: Field Day).

Toolan, Michael (1997) Recentering English: New English and Global, English Today [52] 13(4), pp. 3-10.

Toolan, Michael. Nation languages, local literatures, and international readers: a new indigenization in native English writers?, http://artsweb.bham.ac.uk/MToolan/nationlanguage.html, accessed 29th October 2006.

Tsang, Steve (2004) A Modern History of Hong Kong (Hong Kong: Hong Kong University Press).

Turner, Matthew and Irene Ngan, eds. (1995) Hong Kong Sixties: Designing Identity (Hong Kong: Hong Kong Arts Centre Publications).

Wong Phui Nam (1993) Ways of Exile: Poems from the first decade (London: Skoob Books).

$\mathrm{Xu} \mathrm{Xi}$ and Mike Ingham, eds. (2003) City Voices: Hong Kong Writing in English 1945 to the Present (Hong Kong: Hong Kong University Press). 